Article

\title{
Augustine on Manichaeism and Charisma
}

\section{Peter Iver Kaufman}

Jepson School, University of Richmond, Room 245, Jepson Hall, 28 Westhampton Way, Richmond, VA 23173, USA; E-Mail: pkaufman@richmond.edu

Received: 5 June 2012; in revised form: 28 July 2012 / Accepted: 1 August 2012 /

Published: 3 September 2012

\begin{abstract}
Augustine was suspicious of charismatics' claims to superior righteousness, which supposedly authorized them to relay truths about creation and redemption. What follows finds the origins of that suspicion in his disenchantment with celebrities on whom Manichees relied, specialists whose impeccable behavior and intellectual virtuosity were taken as signs that they possessed insight into the meaning of Christianity's sacred texts. Augustine's struggles for self-identity and with his faith's intelligibility during the late 370s, 380s, and early 390s led him to prefer that his intermediaries between God and humanity be dead (martyred), rather than alive and charismatic.
\end{abstract}

Keywords: arrogance; Augustine; charisma; esotericism; Faustus; Mani; Manichaeism; truth

The Manichaean elite or elect adored publicity. Augustine wrote the first of his caustic treatises against them in 387, soon after he had been baptized in Milan and as he was planning passage back to Africa, where he was born, raised, and educated. Baptism marked his devotion to the emerging mainstream Christian orthodoxy and his disenchantment with the Manichees' increasingly marginalized Christian sect, in which, for nine or ten years, in North Africa and Italy, he listened to specialists - charismatic leaders and teachers. Subsequently he suggested, with regret, that he had believed as they did and had encouraged his friends to respond similarly ([1], 2.19.68; [2], 3.6.11). ${ }^{1} \mathrm{He}$

1. Citations in the text give the book, section, and/or chapter numbers used in editions of Augustine's work, the most accessible of which is on-line at http://www.augustinus.it/latino/index.htm, drawn from volumes 32 to 45 , Patrologia cursus completes, ser. Latina, edited by Jacques Paul Migne and published in Paris from 1844 to 1864. To translate, I have consulted variations cited in relevant volumes of the Corpus Scriptorum Ecclesiasticorum Latinorum and the Corpus Christianorum, series latina. The titles of Augustine's work appear in the reference section, numbered in the order cited. 
accepted the claims that, as a breed set apart, the elect possessed the power to liberate the Light trapped in creation and that what they knew of divinity elevated humanity, in large part, because temptations of the flesh that assailed ordinary others were mere nuisances to them ([2], 3.10.18). But by the time Augustine was baptized, he had ceased trying to convince friends of the Manichaean charismatics' impeccable character and enviable knowledge. Unlike the leadership of mainstream Christianity, who preached humility and shunned celebrity ( $\underline{\text { non }}$ amant propatula), the Manichaean charismatics relished the latter, according to Augustine, who was determined to make them notorious for arrogance and immorality ([3], 2.4).

To do so, he relied on rumor as well as on his own experiences of the specialists' hypocrisy. He said that he had never met one of the elect who was above suspicion of scandal. Most of them, he went on, were petulant; they were a constantly quarrelsome lot, uncivil to their colleagues and condescending to their followers (or "auditors"). Manichaean charismatics were especially contemptuous of critics and seldom disciplined their peers ([1], 2.16.51). On the rare occasion when the outrageous behavior of one of their number was acknowledged, the culpable character could be heard appealing-with success - to the sect's founder, Mani, who supposedly intimated that "its first hero," Adam, was known to have sinned egregiously yet was soon after and long after regarded as righteous ([1], 2.19.72).

Augustine concluded his initial anti-Manichaean screed with the story of an affluent devotee in Rome who tried to rehabilitate the reputation of his sect's elite for holiness. He was not one of the elect but offered them hospitality. They could live comfortably on his estate, if only they conformed to standards of behavior that Mani commended. Augustine implied that their host's generosity would have made a massive difference, if the beneficiaries would have cooperated, yet they did not, and the venture failed. The elect's dedication to the founder was insufficiently influential to attenuate the specialists' dislike-Augustine said "hatred"- of each other. And they lost no love on their auditors, who-much as their host—-seemed eager to wait upon them ([1], 2.20.74). Manichees who picked and prepared fruits and vegetables for the charismatics' meals were not permitted to dine with them, because the elite's eating was its "most sacred" task"; the sect's specialists were "the real saviors," J. Kevin Coyle, explains, saviors, whose mastication and digestion mysteriously released Light from its material prison ([4], p. 310). At his most sarcastic, Augustine imagined gluttonous, self-important charismatics belching sacred Light into heaven after a sumptuous feast, having eaten to excess and having left no morsel for followers ([1], 2.16 .52 and 2.17.57; [5], 5.10; [6], p. 308).

What the charismatic few lavished on followers, Augustine included, were "extravagant promises" ([1], 2.17.55). The elite, that is, promised to supply truths about the cosmos as well as rationally defensible interpretations of Christianity, which, when he turned critic, Augustine took to be “diabolical” distractions. "They kept saying 'truth, truth,' and told me that they had much to reveal, yet there was no truth in them" ([3], 3.6.10). He trusted the sect's teachers, but later, reflecting on his years listening to their promises and explanations, he scolded himself for not having realized that they were "utterly confused" ([3], 14.31). Manichees had persuaded him that no good could come from pursuing truth among the many Christians in congregations that honored no charismatic truth seer or sayer, other than Jesus and his deceased disciples; a sect's elite, however, could satisfy an earnest seeker who wanted a religion that cultured Christians would not despise ([3], 7.17; [7], pp. 219-21).

"I fell in with the Manichees (in tales homines incidisse)," because their teachers promised to make Christianity intelligible. They promised not to resort to superstitions that overawed the unsophisticated 
among the faithful, and they would not intimidate smaller fry. They vowed to set aside their "frightfully exalted authority" and appeal to reason, "pure and simple" (mera et simplici ratione). "Who would not be seduced by such promises" (quis non pollicitationibus illiceretur)? Augustine, then an adolescent "eager to learn the truth" (cupidus veri) and impatient with having been asked or ordered to accept what seemed to be scriptural fictions associated with his mother's more mainstream Christianity, was drawn to the cultic discourses common in Manichaean circles $([3], 1.2){ }^{2}$

Then, in 383, he acquired a new student. An acclaimed Manichaean adept, Faustus, came to Carthage to study classical literature, hoping to learn from Augustine, a lesser Manichee, how to market Manichaeism to cultivated Christians. His new teacher, however, was hoping to learn from Faustus how to make sense of their sect's doctrines. Augustine probed. His pupil resisted ([2], 5.7.12). Augustine's reports of their discussions harp on Faustus's evasiveness and on the sect's unfulfilled promises. They do not complain that his distinguished Manichaean student had explicitly promised anything. Rather, Faustus's reputation preceded him and led Augustine and other local Manichees to expect that their guest would answer all their questions, quasi de caelo, as if he were a celestial oracle ([3], 8.20). François Decret conjectures that Faustus's coming stirred "messianic expectations" ([6], pp. 58-59). Be that as it may, Augustine would almost certainly have thought of Faustus when he groused that Mani, the sect's founder, and other Manichaean charismatics were always promising yet never delivering the truth $([10], 11.12){ }^{3}$

They mocked the faith of ordinary Christians and promised to replace it with a religion based on a sturdier foundation, on what Mani described as "comprehensive solid science" ([10], 13.17). From Augustine's perspective, neither Mani nor Manichaean luminaries who succeeded him supplied anything of the sort. Their promises were seductive and attracted Christians to the Manichees' eccentricities ([12], pp. 244-47; [13], p. 93; [14], pp. 7-9), but Faustus proved to be of no particular importance to Augustine, save, subsequently, as a foil, when he attributed to Faustus's behavior his

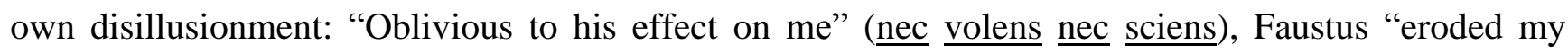
enthusiasm for Manichaeism" ([2], 5.7.13).

Neoplatonism had all but replaced Manichaeism as the interpretive key to Augustine's Christianity by the time he wrote about Faustus's far less than hypnotic effects on Carthaginian Manichees. Nearly fifteen years had passed ([15], p. 44; [16], p. 127). His reflections, no doubt, were affected by what Faustus failed to clarify (and by Manichaean charismatics' misbehavior), yet historian Peter Brown is probably correct to assume that the Manichees' "intense and highly spiritualized relationships" continued to be prized by Augustine. "The mood" of Manichaean cells, their bonds of spiritual

2. I borrow the phrase "cultic discourse" from Jason BeDuhn, who intriguingly suggests that the "vividness" of Augustine's recollections of his adolescent quest for truth may be due to "his close scrutiny of his child's behavior," attention that "most likely reflects an active interest at the time in what it might indicate about human nature" in light of the Manichaean specialists' "teachings" on that topic [8], p. 322, n. 58. Johannes van Oort gathers from the vivid recollections that Augustine found "the Christ-centered character of Manichaeism" irresistible [9], pp. 508-9.

3. Faustus's apparent caution was unusual, if we may trust Augustine, who berated the sect's other accomplished polemicists who were more combative and forthcoming with criticisms of current wisdom ([3], 6.13). Nonetheless, contemporary studies of charismatic leadership contend that "the most challenging and critical period" for leaders attempting to reorient followers "calls for a high level of negation [which] serve[s] the rhetorical function . . . of unfreezing . . . attitudes and values" [11], pp. 472-76). 
friendship, captivated him after the leadership did not-and until something somewhat similar replaced them-specifically, the company of Christian ascetics, who cherished the leisure (otium divinum) to explore what sacred texts and philosophy contributed to their comprehension of creation and who made no extravagant claims to knowledge. ([17], pp. 485-86; [4], pp. 244-48).

What apparently bound Augustine and his like-minded friends together, during their first "retreat" to a country estate near Milan in 386 and, afterward, to his country home in Africa, was their determination to study scripture and what historian Carol Harrison characterizes as a "sense of unworthiness" that clearly distinguished their teacher and leader of their enterprise, Augustine, from the charismatic Manichean elites ([18], p. 31). That distinction, however, did not prevent one early fifth-century critic from complaining that Augustine had organized a new Manichaean cell. He denied it ([19], 3.40.48; [20], p. 94) yet formulated his most striking contrast between his company and Manichaeism years before his critic's protest. In his Concerning The True Religion, Augustine asserted that God assisted "virtuous readers" to comprehend their faith's sacred texts, whereas the Manichaean specialists, who proved to be unable to break their bad habits (consuetudinem suam vincere nequeunt), were destined to misconstrue the meaning of those texts, because they posited a powerful evil, independent of good (and of God), to justify their powerlessness. What started as a character flaw turned into a cognitive crisis; Augustine saw no future for Manichaean exegesis and no good, enlightening result coming from cultic discourse among the Manichees ([21], 9.16).

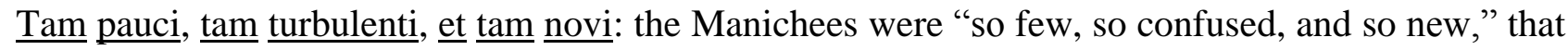
they could not hope for lasting influence. Augustine suspected a glaring contradiction was responsible for their confusion. Their elite often frantically coached and implored listeners to trust them-behavior that belied the specialists' declarations that their doctrine's appeal was due to its self-evident rationality. "Rather than offering their followers reasons to believe [the leadership] demanded that they believe" ([3], 14.31). Augustine's polemics pulled no punches. Relentless and occasionally ruthless, he vilified the sect's teachers as "bloodless," unprincipled, "longwinded, and wretched." $\mathrm{He}$ acknowledged that he had learned from them, but he expressed his gratitude effusively to "the Catholic Church" for having convinced him to reject "absurdities" that the Manichaean charismatics proposed as truths. He urged tepid or "marginal" Manichees to renounce what he had rejected and to embrace what he had accepted, a more orthodox — and less "Persian"-faith, in which they "would not want for the companionship of and for conversations with erudite, truly Christian teachers. Nor would they want for the books and serenity to search them and to sift their thoughts to discover more readily the truths they tried to find" among the Manichees ([3], 18.36). ${ }^{4}$

Although he endorsed measures formulated to coerce Donatist Christians to end their schism, Augustine was uninterested in persecuting Manichees ([24], p. 214; [25], pp. 81-86). Perhaps he remembered the effects of anti-Manichaean edicts on his career. He moved from Carthage to Rome and then to Milan to avoid regional officials trawling for Mani's admirers. After he defected, during

4. Ita tibi neque praecepta et disputations $\underline{\text { doctissimorum hominum et vere christianorum, neque libri, neque serenae ipsae }}$

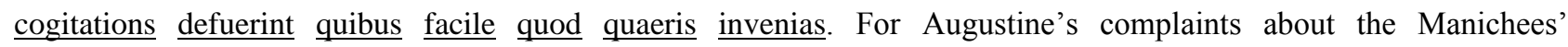
inconsistencies in this polemic, see [9], pp. 433-34; for his interests in (and appeals to) "marginal" Manichees, see [22], p. 191. But, predictably, as Johannes van Oort astutely notes, such a mission tempted Augustine to make some exegetical blunders [23], p. 138. 
the 420s, enforcement became especially relentless ([12], 2, 176), yet crisis is now acknowledged by scholars who tend to agree with Max Weber to breed charismatic leadership. Crisis can elicit the courage, nobility, ingenuity, agility, and exceptional sensitivities to context, traits that line up well with what Weber recognized as charismatic virtuosity and with the profound inspiration he expected charismatic leaders to provide [26]. Government officials supplied the political crisis that kept followers attentive to the Manichaean elite, the teachers populating this study as charismatic specialists, but a crisis of intelligibility was equally-or conceivably more-responsible for the specialists having received special status.

Christians demanded explanations. Their religion's statements about God, good, and evil raised questions, for which the Manichaean specialists claimed to have answers. At first, and for years, Augustine trusted them. But he came to understand the enormity of the challenge and his charismatic colleagues' inability to meet it: non solum homines sed etiam insipientes homines sumus; "we are not only human but unwise," having finite minds incapable of comprehending infinite truths ([1], 1.7.11). ${ }^{5}$ Hence, God's assistance was indispensable, and no teacher could do what only an ardent seeker's submission to truth in faith could accomplish. Faith, accompanied by desire and virtue made the difference ([3], 10.24). Of course there were Christian specialists affiliated with emergent orthodoxy, whom the Manichaean elect censured, but to whom seekers might repair for assurances that the mysteries of their faith were both beyond knowing, yet true. Augustine maintained that mainstream Christianity's scholars and church administrators, unlike Manichaean specialists, were uncharismatic and, as noted, cared nothing for notoriety ([3], 2.4).

For their part, the Manichaean elect seem to have conformed to what is now expected of charismatic leaders; they crafted a claim to superior righteousness and knowledge to undermine conventional norms, "exercis[ing] diffuse and intensive influence over [others'] normative and ideological orientations" ([11], pp. 459, 465-66). Augustine was alarmed by precisely that. He was indignant and distressed. He allowed, however, that his indignation promptly turned to pity whenever he pondered his former friends' inability to resolve the crisis of intelligibility with the reasons proffered by Manichaean specialists who seemed to be incapable of knowing their own "unknowing" (insipientia) and of discerning the signs of God's love in the church's sacraments ([2], 9.4.8).

Jason Beduhn's excellent, comprehensive study of the Manichaeism and anti-Manichaeism of Augustine's early years identifies the "recurring part[s]" of his protagonist's "outlook." He supposes that a "predilection for esotericism" first attracted his protagonist to Manichaean versions of Christianity and held his interest for nearly a decade. Disenchanted eventually with the sect's elect and drifting away, during his interviews with Faustus - if not before - from its cultic discourse, Beduhn's Augustine retained "high expectations of revealed knowledge" yet disavowed the expectation that complete sanctification and comprehension could come upon any of the sect's specialists. Augustine

5. Cornelius Mayer elaborates on Augustine's passage, linking it with Plato's sense that a cloud of unknowing (eine Wolke der Torheit) separates seekers from the enlightenment they desire ([27], p. 60, and Carol Harrison usefully comments on the problems of theodicy that posed "seemingly unanswerable questions," creating, for Christians, what I term a crisis of intelligibility ([18], pp. 74-75). 
figured that insight came with faith, and faith was the onset of "a gradual conformation to a system as one learns it more thoroughly and keeps adjusting one's sense of self' ([8], pp. 241-43).

The founder of Manichaeism might have agreed, to a point. The sect's listeners were gradually "adjusting" as they learned the truths imparted by the elect and understood that the temptations to wickedness which they experienced were symptoms of a powerful evil other's seizure; their wills were captive. But the charismatic specialists who succeeded Mani and who purportedly resisted temptation lay claim to authority on the strength of that resistance, which - with acquired intelligence that enabled them to ascertain the presence and power of evil as well as the presence of Light in creationdistinguished them from listeners, learning and "adjusting" gradually. Augustine joined the chorus of complaints prompted by such a distinction. The first anti-Manichaean script, the Acta Archelai, was circulating fifty years before he heaped abuse on Mani's pretensions. It supplies accounts of two debates said to have occurred between Mani and Archelaus, bishop of Carchar, located in Persian territory, one hundred-or-so miles from Roman garrisons. According to the Acta, the bishop prevailed in both confrontations. Mani twice fled, and the description of his humiliations introduces an extremely unflattering biography of the vanquished, to which sketches of others are annexed to show that Mani, "devious" as well as defeated ([28], 26.6), stole his ideas from previous mythmakers. Nothing about Mani appears unassailable; his originality, honesty, and intelligence were casualties of what still reads as a fractiously effective effort to undermine his celebrity and authority. Did Augustine know of Archelaus's scalding accusations? Perhaps so, inasmuch as Faustus looks to have been contemplating a reply during his studies in Carthage ([8], p. 331, note 15).

If a reply was composed and circulated, it got lost, yet historians have lately engaged in the rescue Faustus might have tried; the recovery of long lost Manichaean literature has helped them rehabilitate Mani's reputation. Hence, few scholars familiar with Christian antiquity would now dissent from the favorable observations on offer in Geo Widengren's concise introduction to Mani and Manichaeism, which was published in the 1960s and which featured Mani's "vigorous sense of mission." Widengren's Mani comes across as impressively resourceful. "Ahead of his time" he had a gift for "blend[ing]" ritual with reasoning and exhibited "astonishing vigor and versatility" ([29], pp. 140-44). It seems reasonable to infer that Mani similarly struck the author of the Acta (and-arguablyArchelaus as well), because the polemic went to such great lengths to deploy what Eszter Spät now calls "romance elements" and ad hominem sidebars to discredit him [30]. What we learn from late antique heresiology as well as from Mani's relatively recent recuperation, however, enables us to dock him (and the Manichaean specialists who succeeded him) alongside Weberian standards for charisma and the popular notions described by Dickson [26]. Surely we should take Mani's insistence that he was the Paraclete, the divine spirit whose return had been forecast in the Gospel of John, as a bid for exceptional status, often awarded heroes of the faith and incarnate-deities-turned-inspirationalleaders ([28], 37.3). And Mani's now touted versatility, evident in his mixing Persian myth — as well as other ingredients - with Christian faith ([31], p. 212) suggests that he ought to be reckoned among charismatics who, Dickson astutely notices, become impresarios of their own celebrity. But what distinguishes Mani from the conventional members of that unconventional corps - and what will bring Augustine back into our story, is the function of scandal.

As Dickson rightly says, in the second and un-Weberian sense of charisma, a charismatic leader, performer, or seer may be well served by "a whiff of scandal" [26]. Yet Augustine knew that scandal 
discredits Manichaean specialists' claims to superior righteousness and truth. They boasted of possessing both. Colleagues studying charismatic leadership of late suggest scandals diminish the effectiveness of the "techniques" that bind charismatics to followers; when high standards for-and the professed values of-charismatic leaders are compromised, followers' attachments to those charismatics' "ideological vision[s]" erode ([11], p. 453).

Augustine was intent on turning the "whiff" or scent of scandal into a stink. According to François Decret, his objective was "to aggravate the tensions" between the sect's "aristocracy of virtue" and other Manichees who presumed their charismatic leaders would be virtuous. Decret thinks the tension was characteristic of the Manichees' organization - the structure ecclésiastique, which, admittedly, is hard to reconstruct ([12], 1, p. 35). Still, we have learned that Augustine appreciated sect solidarity and prized intellectual conversations with amiable colleagues. He explained that friendships kept alive his hopes that swaggering charismatic specialists might reveal something meaningful. But he later declared that those friendships were the links in a chain choking him (inuosum vinculum) and sustaining his unrealistic expectations of what Manichaean specialists would divulge ([32], 9.11).

Augustine wanted answers and was led to believe that Faustus would furnish them. He later referred to what he got as nonsense, nugae ([8], pp. 103-105; [10], 23.25), yet he thought that it was treacherous nonsense. One can imagine him overcoming his disappointment more easily after converting to a less gnostic Christianity and avoiding a long controversy with his former colleaguesor at least sheathing his polemical sword sooner-had he not become convinced that Manichaean specialists were drawing away the faithful by misconstruing ("mangling") Christianity's sacred texts. They and he agreed: a consensus evangelistarum constituted the bedrock of revelation and had to be both formulated and explained to more imperceptive Christians. To do so, the sect's elite exegetes had tossed aside the Hebrews' contributions to Christianity's sacred literature and proposed purportedly rational-but, to Augustine, chillingly heretical-interpretations of what remained. Manichaean specialists imagined duels everywhere; they depicted the cosmos as a battlefield on which God and the good fought evil. The Old Testament had to be jettisoned for the New to be true. Duels and dualism made the world intelligible to them. They refused to trust what Augustine perceived finally as "a single master purpose" after his faith in a "secure providential order of things" disposed him to give the Manichees' "fatalistic indeterminism" a pass ([8], pp. 264-65).

Reflections on exegesis, dualism, and doctrine tell much of the tale, but Augustine's disaffection during the 380s was also a reaction to the sect's charismatic specialists'- to him-determinedly indecorous behavior and disingenuous claims. In a study that rarely touches on Augustine's developing antagonism toward the Manichaean elect, Peter Brown noticed that his subject transferred affections encouraged in late Roman culture, specifically, the "deep warmth for teachers and spiritual guides," to Christianity's martyrs. "Heavy with the humility of human death" ([33], pp. 59-60), the martyrs could not scuttle, or mangle texts or wed rationality to the Christian faith to the detriment of the latter, or misbehave and spawn scandals. The martyrs were intermediaries, much as the Manichaean specialists, but they would not do what the latter ("false, deceitful men") had done to Augustine. They could not "dig up" (effodere) the seeds of the truth his mother planted in him; they would not have distracted him and kept him from returning to the emergent, orthodox Christian faith for over a decade ([33], 1.1).

Jason BeDuhn appropriately warns against exaggerating Augustine's transformation - his apostasy from Manichaeism and conversion to Nicene Christianity. A reasonable reading of the relevant texts 
suggests that he subordinated a desire for "self-intelligibility" to related "systems" of Christianity, finding "that he constantly had to reinvent what his conversion would mean for him as he continued to discover the potential of his adopted system and of himself as its point of articulation "in the face of the Manichaean challenge" ([8], pp. 301-302). Still, by the late 380s, he was reluctant to trust enterprising and ostensibly compelling figures who, in the judgment of others, were celebrated guides. Faustus disappointed him. Bishop Ambrose of Milan, who was an astute administrator and charismatic Nicene (or mainstream) Christian — and whose oratory he admired — became more a foil than a friend and regular correspondent ([25], pp. 15-24). It would appear that Manichaeism left Augustine suspicious of charismatics' claims upon devotees' credulity. And his suspicions endured as other "specialists"-Christian continetes, Donatist bishops and martyrs, and Pelagian moral theoristsdisplayed what he perceived as pride in acquired virtues.

\section{References}

1. Augustine. De moribus ecclesiae Catholicae et de moribus Manichaeorum.

2. Augustine. Confessiones.

3. Augustine. De utilitate credendi.

4. J. Kevin Coyle. Manichaeism and Its Legacy. Leiden: Brill, 2009.

5. Augustine. Contra Faustum Manicheum.

6. François Decret. Aspects du Manichéisme dans l'Afrique Romain. Paris: Études Augustiniennes, 1970.

7. Andreas Hoffmann. Augustinus Schrift, "De utilitate credendi”. Münster: Aschendorff, 1997.

8. Jason David BeDuhn. Augustine's Manichaean Dilemma, 1: Conversion and Apostasy, 373-388 C.E. Philadelphia: University of Pennsylvania Press, 2010.

9. Johannes van Oort. "Manichaean Christians in Augustine's Life and Work." Church History and Religious Culture 90 (2010): 505-546.

10. Augustine. Contra epistulam Manichaei quam vocant Fundamenti.

11. C. Marlene Fiol, Drew Harris, and Robert House. "Charismatic Leadership: Strategies for Effecting Social Change.” Leadership Quarterly 10 (1999): 449-82.

12. François Decret. L'Afrique Manichéenne (IV -V ${ }^{a}$ siècles). Paris: Études Augustiniennes, 1978, 2 vols.

13. Richard Lim. Public Disputation, Power, and Social Order in Late Antiquity. Berkeley: University of California Press, 1995.

14. Sabine MacCormack. “Augustine Reads Genesis.” Augustinian Studies 39 (2008): 5-47.

15. Roland J. Teske, S.J. "The Heaven of Heaven and the Unity of St. Augustine's Confessions." American Catholic Philosophical Quarterly 74 (2000): 29-45.

16. L.J. van der Lof. "Der numidische Manichäismus im vierten Jahrhundert." Studia Patristica 8 (1966): 118-29.

17. Peter L. Brown. Augustine of Hippo: A Biography. Berkeley: University of California Press, 2000.

18. Carol Harrison. Rethinking Augustine's Early Theology. Oxford: Oxford University Press, 2006.

19. Augustine. Contra literas Petiliani. 
20. Jason David Beduhn. "Augustine Accused: Megalius, Manichaeism, and the Inception of the Confessions." Journal of Early Christian Studies 17 (2009): 85-124.

21. Augustine. De vera religione.

22. Annemaré Kotzé. "The Anti-Manichaean Passage in Confessions 3 and its Manichaean Audience." Vigiliae Christianae 62 (2008): 187-200.

23 Johannes van Oort. “Augustin und der Manichäismus.” Zeitschrift für Religions-und Geistesgeschichte 46 (1994): 126-42.

24. Madeleine Scopello. "L'Epistula Fundamenti à la lumière des sources manichéennes du Fayon." In Augustine and Manichaeism in the Latin West, Johannes van Oort, Otto Wermelinger, and Gregory Wurst, Eds. Leiden: Brill, 2001, 205-221.

25. Peter Iver Kaufman. Incorrectly Political: Augustine and Thomas More. Notre Dame: University of Notre Dame Press, 2007.

26. Gary Dickson. "Charisma, Medieval and Modern.” Religions 3 (2012): 763-789.

27. Cornelius Mayer. "Garanten der Offenbarung: Probleme der Tradition in den antimanichäischen Schriften Augustins.” Augustinianum 12 (1972): 51-78.

28. Hegemonius. Acta Archelai. Louvain: Brepols, 2001.

29. Geo Widengren. Mani and Manichaeism. New York: Holt, Rinehart, and Winston, 1965.

30. Eszter Spät. "The 'Teachers' of Mani in the Acta Archelai and Simon Magus." Vigiliae Christianae 58 (2004): 1-23.

31. Madeleine Scopello. "Vérités et contre-vérités: La vie de Mani selon les Acta Archelai." Apocrypha 6 (1995): 203-24.

32. Augustine. De duabus animabus.

33. Peter L. Brown. The Cult of the Saints: Its Rise and the Function in Latin Christianity. Chicago: University of Chicago Press, 1981.

(C) 2012 by the author; licensee MDPI, Basel, Switzerland. This article is an open access article distributed under the terms and conditions of the Creative Commons Attribution license (http://creativecommons.org/licenses/by/3.0/). 